\title{
XXIII. Extract of a Letter from Capt. Thomas Hutron, H. E. I. C., to J. O. Westwood, Esq.
}

[Read November 1st, 1847.]

\author{
Mussooree, Himalaya Mountains. \\ 28th July, 1847.
}

My dear Sir,

I HAVE long contemplated writing to you, and now that the last mail has brought me the intelligence that you have been kind enough to honour me by naming the new Bombyx after me, I cannot allow the post to go out without expressing to you my best thanks for your attention and remembrance of me.

I have nearly made up my mind to make a run home for one year, and in that case shall bring the few insects I have by me, and trust there may be some more novelties worthy of your attention. In the mean time I must tell you that I have again this year reared specimens of Actias Selene, and observed attentively the method by which it cuts its way through the cocoon; and there can be no doubt of the correctness of my former observations in regard to the wing spur, from which I derived the name "Plectropteron," a name which I think, from the novelty of the circumstance, may still hold good, and the species would therefore stand as $P$. Selene, my $P$. Diance sinking into a synonyme; it is, as I formerly observed, most probable that Actias luna possesses the same spur; and the new species lately sketched in the Annals and Magazine of Natural History, under the name of $A$. Manas, most probably possesses it likewise, in which ease there would be three species so armed, and forming a good genus characterised as Actias, with the addition of the wing spur; and at all events the characters of Actias must be remodelled, before $A$. Selene can find a place in it.

The habitat of $A$. Manas is very confusedly given in the Magazine of Natural History, it being stated the species is from Sylhet, and yet that it is from "Northern India." Sylhet is to the eastward, not northward.

Let me now call your attention more particularly to the instrument which I have named " the wing spur;" that instrument is not the part you thought I alluded to in my notice of the insect, but is totally distinct from it, and projects from the joint of the wing. The part you alluded to, viz. the tippet, (tegula or ptery- 
goid), I have detached, and placed separately a spur and a wing in the inclosed paper. And you will still see, on the shoulder joint of the wing, a strong, hard, black spur, with a sharp point and cutting edge. The point of this instrument is thrust through the cocoon, and the cutting edge drawn across the fibres, until severed sufficiently to enable the moth to come forth. Place the wing horizontally before your eye, and look from the anterior edge along the apex, and the spur will be visible.

Of the "Bombyx Huttoni," I will bring home specimens of the perfect insect, and also their eggs, in order that you may see the caterpillars. Cocoons and samples of the silk wound off also.

I hope the Actias may be worthy of notice in your new work, which I have not yet had an opportunity of seeing; and that you will give dissections of the wing, in order to show the spur. If I can get some autumn cocoons I will bring them or send them, in order that you may see the process, and seeing believe!

Cheirotonus Mc Leayii is not a rare insect, although a very local one. Several occur in private collections here, but I cannot get them. I have one male slightly injured in the elytra, and a diminutive male. It is a sap feeder, and may be seen in company with crowds of stag beetles, sucking up the juice as it flows from wounds in the trees. They breed in decaying oak trees (quercus incana). I sent you a notice of some butterflies long since, which I hope you received. 

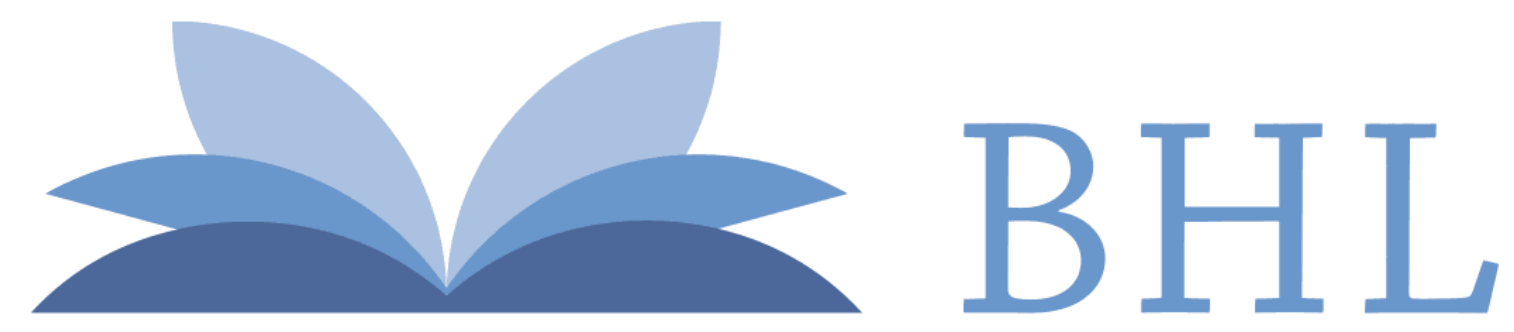

\section{Biodiversity Heritage Library}

1848. "XXIII. Extract of a Letter from Capt. Thomas Hutton, H. E. I. C., to J. O. Westwood, Esq." Transactions of the Entomological Society of London 5, 85-86. https://doi.org/10.1111/j.1365-2311.1848.tb02976.x.

View This Item Online: $\underline{\text { https://www.biodiversitylibrary.org/item/51010 }}$

DOI: https://doi.org/10.1111/j.1365-2311.1848.tb02976.x

Permalink: https://www.biodiversitylibrary.org/partpdf/38513

\section{Holding Institution}

Smithsonian Libraries

\section{Sponsored by}

Smithsonian

\section{Copyright \& Reuse}

Copyright Status: Public domain. The BHL considers that this work is no longer under copyright protection.

This document was created from content at the Biodiversity Heritage Library, the world's largest open access digital library for biodiversity literature and archives. Visit BHL at https://www.biodiversitylibrary.org. 